\title{
Meta-analysis
}

\section{The Ala allele in the PPAR- $\gamma 2$ gene is associated with reduced risk of type 2 diabetes mellitus in Caucasians and improved insulin sensitivity in overweight subjects}

\author{
Grazielle Vilas Bôas Huguenin ${ }^{1}$ and Glorimar Rosa ${ }^{2} *$ \\ ${ }^{1}$ Instituto de Nutrição, Universidade do Estado do Rio de Janeiro, Rio de Janeiro, Brazil \\ ${ }^{2}$ Departamento de Nutrição e Dietética, Instituto de Nutrição Josué de Castro, Universidade Federal do Rio de Janeiro, \\ Rio de Janeiro, Brazil
}

(Received 6 September 2009 - Revised 21 January 2010 - Accepted 22 January 2010 - First published online 27 April 2010)

\begin{abstract}
The purpose of the present study was to identify the association of the Pro12Ala polymorphism in the PPAR- $\gamma 2$ gene with diabetes, insulinaemia and insulin resistance. A meta-analysis study was carried out based on studies conducted in the last 10 years, using the databases PubMed, ISI Web of Knowledge, High Wire Press and Scielo, and the reference lists of the obtained articles. We included original studies that showed the relationship between the Pro12Ala polymorphism in the PPAR- $\gamma 2$ gene and type 2 diabetes mellitus (T2DM), insulinaemia and insulin resistance. Statistical analyses were conducted using the program RevMAn 5.0. The Mantel-Haenszel test was used to estimate the OR and the $95 \%$ CI of the dichotomous variable, while the standardised effect size was used to estimate the average standardised mean difference and $95 \%$ CI of continuous variables. The studies were subgrouped by ethnicity and overweight status. Forty-one studies were analysed, including a global sample of 30612 subjects. We found a significant association of the Ala allele with the lowest risk of T2DM in Caucasians (OR 0.80; $95 \%$ CI $0.65,0.98$ ), lower serum insulin (standardised effect size: $-0.05 ; 95 \%$ CI $-0.09,-0.00 ; P=0.04$ ), and greater sensitivity to insulin in overweight individuals (homeostasis model assessment of insulin resistance standardised effect size: $-0 \cdot 07 ; 95 \% \mathrm{CI}-0 \cdot 13,-0 \cdot 01 ; P=0 \cdot 02$ ). Considering that the Pro12Ala polymorphism in the PPAR- $\gamma 2$ gene is one of the factors related to insulin sensitivity, the present study demonstrated a significant effect of the Ala allele on lower development of T2DM in Caucasians and greater sensitivity to insulin in overweight subjects.
\end{abstract}

Meta-analyses: Human PPAR- $\gamma 2$ polymorphism: Type 2 diabetes mellitus: Insulin resistance

PPAR- $\gamma 2$ is a nuclear receptor transcription factor, and its codifying gene, on chromosome $3 \mathrm{p} 25$, is intensively expressed in adipose tissue ${ }^{(1)}$. PPAR- $\gamma 2$ regulates lipid metabolism, adipocyte differentiation, proliferation and insulin sensitivity through regulation of the expression of adipocyte-specific developmental genes ${ }^{(2)}$.

Additionally, there is a missense C-to-G change in codon 12 encoding alanine in substitution for proline in the polypeptide sequence. This polymorphism is relatively common, occurring in $20 \%$ of the Caucasian population ${ }^{(3-5)}$, and seems to be responsible for reduced activity of PPAR- $\gamma 2^{(6)}$.

A few studies have identified an association between the Ala allele and improvement in insulin resistance ${ }^{(3,7-9)}$. Because the polymorphism is very close to the amino-terminal-activated independent binding domain, its activity is increased by insulin through phosphorylation. It seems that, while proline prevents the $\alpha$-helix, alanine favours it, and this amino acid change can exert a profound effect on the structure and, consequently, the function of this $\operatorname{protein}^{(10)}$.
Given the controversy generated by the studies that report an association between the most frequent polymorphism in the PPAR- $\gamma 2$ gene and insulin resistance and diabetes, and also considering that insulin resistance is accountable for promoting metabolic alterations that increase cardiovascular risk in subjects, the present study aimed to identify systematically the association of the Pro12Ala polymorphism in the PPAR- $\gamma 2$ gene with type 2 diabetes mellitus (T2DM), insulinaemia and insulin resistance in Caucasians and non-Caucasians and based on overweight status.

\section{Methods \\ Research design}

The present investigation was carried out within a limited period of 10 years, from 1998 to June 2008, using the keywords: ('1998'[publication date]:'2008/06' [publication date]) and ((PPAR $\gamma 2$ polymorphism or peroxisome

Abbreviations: HOMA-IR, homeostasis model assessment of insulin resistance; T2DM, type 2 diabetes mellitus.

* Corresponding author: Dr Glorimar Rosa, fax +55 212280 8343, email glorimar@nutrição.ufrj.br 
proliferator-activated receptor) and ('insulin resistance' or 'insulin sensitivity' or 'diabetes' or 'impaired glucose tolerance')) and refined by 'humans', 'clinical trial', 'editorial', 'letter', 'meta-analysis', 'randomized controlled trial', adult: 19-44 years, middle aged: 45-64 years, middle aged + aged: $45+$ years, aged: $65+$ years, 80 and over: 80 + years. The search was performed initially on the PubMed website, which resulted in 152 studies. Other databases were accessed to obtain the full-text articles: ISI Web of Knowledge, MEDLINE, SCIELO, High Wire Press and Science Direct. The reference lists of the original research articles and review articles were used to complement the database search by including additional publications that would not show up in the PubMed search.

Selection of studies was performed independently by two interviewers according to the following exclusion criteria: (1) articles written in languages other than English, Spanish and Portuguese; (2) review articles; (3) missing genotypespecific case numbers or measurement data of fasting insulin or homeostasis model assessment of insulin resistance (HOMA-IR) or diabetes; (4) modified results of fasting insulin or HOMA-IR by log or geometric means; (5) missing measurement of deviation; (6) calculation of HOMA-IR by formulas other than the original represented by Matthews et $a{ }^{(11)}$; and/or (7) a genotype distribution not in HardyWeinberg equilibrium. Thus, four studies were excluded on the basis of the continuous variables, one due to missing deviation data ${ }^{(12)}$, and another as it transformed data into logarithms to normalise their distribution ${ }^{(2)}$; the final excluded studies $^{(13,14)}$ calculated insulin resistance by formulas other than HOMA-IR ${ }^{(11)}$.

Forty-one studies were selected for analysis, and all relevant data were extracted individually from each study, including first author, year of publication, country, ethnicity, total number of each genotype of Pro12Ala polymorphism, number of cases representing T2DM and impaired glucose tolerance and controls by normal glucose tolerance and mean and standard deviation for age, BMI, fasting insulin and HOMA-IR.

\section{Data analysis}

All analyses were performed on the genotypes Pro12Pro (Pro/Pro) and the sum of Pro12Ala with Ala12Ala (X/Ala). To calculate the mean and standard deviation of X/Ala in some studies presenting separate data, the sum of variances within and between genotypes was used. The same formula was used to group impaired glucose tolerance and diabetes.

When necessary, data were transformed from standard error into standard deviation using the specific formula $\mathrm{SD}=\mathrm{SE} \times \sqrt{ } n$. In addition, serum insulin values presented in $\mu \mathrm{IU} / \mathrm{ml}$ were converted into $\mathrm{pmol} / \mathrm{l}$ by the conversion factor $6 \cdot 945^{(15)}$.

Data were analysed by RevMan (version 5.0; The Cochrane Collaboration, Copenhagen, Denmark $)^{(16)}$. The OR of the Ala allele and T2DM association was calculated by a MantelHaenszel test ${ }^{(17)}$. The inverse of variance with standardised mean difference was used to estimate the association of the Ala allele with serum insulin and HOMA-IR. This measure represents the standardised size effect of polymorphic genotypes (X/Ala) in relation to the wild genotype (Pro12Pro) in fasting serum insulin and HOMA-IR levels. In the course of the analysis, the studies were separated into subgroups to calculate the summary measure in each subgroup and the overall final measure. The subgroups took into account ethnicity, separating Caucasians from non-Caucasians; the subgroups were also divided according to overweight status, separating the studies that showed an average population of normal BMI $\left(<25 \mathrm{~kg} / \mathrm{m}^{2}\right)$ and increased mean BMI $\left(>25 \mathrm{~kg} / \mathrm{m}^{2}\right)$, classifying them as normal weight and overweight, respectively. The lack of data about the ethnicity of the studies' populations led us to consider as Caucasian those who have ancestry and were born in Europe, or the Middle East, or North Africa, or parts of Central Asia, who share certain genetic and physiological characteristics, beyond white skin.

Statistical analysis of serum insulin in the combination of studies in a population group with normal glucose tolerance and another group with impaired glucose tolerance and T2DM was performed in order to verify that the Ala allele influences the concentration of insulin under different conditions of glucose tolerance.

To assess the statistically significant heterogeneity between studies, a $\chi^{2}$ test with $n-1 \mathrm{df}$ was used, where ' $n$ ' is number of studies. In the case of significant heterogeneity in the global analysis, a random-effects model was calculated; otherwise, a fixed-effects model was calculated. Inconsistency $\left(I^{2}\right)$ was calculated to verify how much of the difference between studies was caused by heterogeneity, with values lower than $25 \%$ considered low, $50 \%$ considered moderate, and values greater than $75 \%$ considered high inconsistency ${ }^{(18)}$. A $Z$ test was used to analyse the global effect and the CI. Significance was assumed at $P<0.05$.

The outcomes on the left axis that cross the scale ( 1 or 0 ) indicate that the corresponding amount is smaller in the $\mathrm{X} / \mathrm{Ala}$ genotype than the Pro/Pro genotype.

\section{Results}

Forty-one eligible studies from the past 10 years were included in the meta-analysis, all of them in Hardy-Weinberg equilibrium. Table 1 describes the main features of each study group while Figs. 1-3 describe the OR and 95\% CI of each group (see below). Citations denoted a, b, c or d represent the same study with different populations.

The association of the Ala allele with T2DM (Fig. 1) included twenty-four studies that showed heterogeneity $(P<0.00001)$. In the overall analysis, the Ala allele had a significant protective association (OR $0.79 ; 95 \%$ CI 0.66 , 0.95). Regarding ethnic differences, the Caucasian subgroup showed a significantly lower risk of developing diabetes for the Ala allele $(P=0.03)$; however, this protective association was not observed among non-Caucasians $(P=0 \cdot 21)$. Both groups proved to be heterogeneous, but this result disappeared when the Caucasian study Soriguer et al. ${ }^{(19)}$ was deleted (heterogeneity $P=0 \cdot 10$; OR 0.86 , $95 \%$ CI 0.75 , $0 \cdot 98, P=0 \cdot 02)$.

Was also calculated the association between the Ala allele and T2DM according to BMI; both subgroups, normal weight (n 3) and overweight ( $n$ 16), showed little association (OR $0.40,95 \%$ CI $0.25,0.66, P=0.0004$ and OR $0.89,95 \%$ CI $0.80,0.99, P=0.04$, respectively). The overweight subgroup presented heterogeneity $(P=0.03)$, while the normalweight subgroup was homogeneous $(P=0 \cdot 47)$. The total $n$ of 


\begin{tabular}{|c|c|c|c|c|c|c|c|c|c|}
\hline \multirow[b]{2}{*}{ Study ${ }^{*}$} & \multirow[b]{2}{*}{ Reference } & \multirow[b]{2}{*}{ Subjects $(n)$} & \multirow{2}{*}{$\begin{array}{r}\text { Ala allele } \\
\text { frequency }\end{array}$} & \multirow[b]{2}{*}{ Study population } & \multicolumn{2}{|c|}{ Age (years) } & \multicolumn{2}{|c|}{$\mathrm{BMI}\left(\mathrm{kg} / \mathrm{m}^{2}\right)$} & \multirow[b]{2}{*}{ Observations } \\
\hline & & & & & Mean & SD & Mean & SD & \\
\hline Andrulionytè (2004) & 20 & 770 & 0.23 & Mixed & 54 & 4 & $30 \cdot 8$ & $4 \cdot 1$ & STOP-NIDDM (multicentre) \\
\hline Altshuler (2000)a & 27 & 962 & 0.25 & Caucasian & 60 & 10 & $27 \cdot 5$ & 4.6 & Case-control, Scandinavia, T2DM + IGT severe v. NGT \\
\hline Altshuler $(2000) \mathrm{b}$ & 27 & 254 & 0.18 & Caucasian & 52 & 8 & $29 \cdot 0$ & 4.5 & Case-control, Quebec, T2DM v. NGT \\
\hline Baratta (2003) & 39 & 338 & 0.12 & Caucasian & 37 & 12 & $27 \cdot 0$ & 5.9 & Non-diabetic, Sicilian \\
\hline Beamer (1998)a & 40 & 57 & 0.17 & Caucasian & 44 & 11 & 38.4 & $6 \cdot 4$ & JHU-WMC, non-diabetic, men \\
\hline Beamer (1998)b & 40 & 112 & 0.16 & Caucasian & 43 & 10 & 35.4 & $9 \cdot 2$ & JHU-WMC, non-diabetic, women \\
\hline Beamer (1998)c & 40 & 316 & 0.22 & Caucasian & 64 & 15 & $26 \cdot 9$ & 3.4 & BLSA, non-diabetic, men \\
\hline Beamer (1998)d & 40 & 201 & 0.19 & Caucasian & 63 & 17 & $25 \cdot 8$ & $5 \cdot 0$ & BLSA, non-diabetic, women \\
\hline Buzzetti (2004) & 31 & 1215 & $0 \cdot 17$ & Caucasian & 42 & 13 & $32 \cdot 7$ & $9 \cdot 2$ & Non-diabetic, Italian \\
\hline Clement (2000)a & 33 & 372 & $0 \cdot 11$ & Caucasian & 43 & 11 & $47 \cdot 2$ & 7.5 & Morbidly obese (T2DM and NGT) \\
\hline Clement $(2000) \mathrm{b}$ & 33 & 697 & 0.08 & Caucasian & 55 & 9 & 26.4 & $5 \cdot 7$ & T2DM v. NGT \\
\hline Deeb (1998)a & 7 & 333 & 0.23 & Caucasian & 44 & 14 & $25 \cdot 9$ & 3.3 & Non-diabetic, middle-aged, Finnish \\
\hline Deeb (1998)b & 7 & 973 & 0.29 & Caucasian & 70 & 0.6 & $27 \cdot 4$ & $5 \cdot 1$ & Elderly subjects, Finnish (T2DM and NGT) \\
\hline Deeb (1998)c & 7 & 299 & 0.08 & Japanese-American & - & & - & & Nissei, T2DM + IGT v. NGT \\
\hline Douglas (2001)a & 9 & 220 & 0.22 & Caucasian & 70 & 0.3 & $27 \cdot 0$ & 4.0 & FUSION, Finnish, non-diabetic, elderly \\
\hline Douglas (2001)b & 9 & 193 & 0.19 & Caucasian & 61 & 7 & 28.4 & 4.5 & FUSION, Finnish, non-diabetic \\
\hline Douglas (2001)c & 9 & 522 & 0.15 & Caucasian & 63 & 7 & $30 \cdot 0$ & 4.8 & FUSION, Finnish, diabetic \\
\hline Ek (2001)a & 3 & 616 & 0.25 & Caucasian & 70 & & $25 \cdot 6$ & 3.1 & Swedish men, NGT \\
\hline Ek (2001)b & 3 & 364 & 0.26 & Caucasian & 25 & 3 & 23.4 & 3.5 & Healthy, Danish \\
\hline Ek (2001)c & 3 & 1396 & 0.24 & Caucasian & - & & - & & Copenhagen, T2DM ( $n$ 654) v. NGT $(n 742)$ \\
\hline Ek (2001)d & 3 & 841 & 0.25 & Caucasian & 70 & & - & & Swedish men, NGT ( $n$ 616), T2DM + IGT ( $n$ 225) \\
\hline Eurlings (2003)a & 4 & 79 & 0.28 & Caucasian & 50 & 10 & $27 \cdot 2$ & 3.0 & Cases (T2DM), FCHL, Dutch \\
\hline Eurlings (2003)b & 4 & 124 & 0.25 & Caucasian & 51 & 11 & $25 \cdot 3$ & 3.9 & Controls (NGT), FCHL, Dutch \\
\hline Frederiksen (2002) & 41 & 2245 & 0.26 & Caucasian & $40-70$ & & $25 \cdot 8$ & $4 \cdot 1$ & Non-diabetic \\
\hline Hara (2000)a & 8 & 541 & 0.08 & Japanese & 69 & 5 & $23 \cdot 8$ & $3 \cdot 1$ & Non-diabetic \\
\hline Hara (2000)b & 8 & 415 & 0.04 & Japanese & 61 & 10 & 23.5 & 4.0 & T2DM \\
\hline Hegele (2000) & 2 & 290 & $0 \cdot 18$ & Caucasian & 35 & 14 & $29 \cdot 2$ & 5.5 & Women, Canadian, T2DM + IGT v. NGT \\
\hline Jaziri (2006) & 42 & 229 & 0.08 & Caucasian & $30-64$ & & - & & DESIR, French \\
\hline Lindi (2002) & 43 & 490 & 0.31 & Caucasian & 55 & 8 & $31 \cdot 2$ & 4.6 & DPS, IGT, Finnish \\
\hline Lindi (2003)a & 44 & 150 & 0.20 & Caucasian & 49 & 7 & $26 \cdot 5$ & 2.9 & KANWU, non-diabetic (NGT + IGT) \\
\hline Lindi (2003)b & 44 & 72 & 0.29 & Caucasian & 49 & 7 & $26 \cdot 9$ & 3.0 & KANWU, supplementation $n-3$ (NGT + IGT) \\
\hline Kao (2003) & 12 & 1441 & 0.04 & African-American & 53 & 5 & $29 \cdot 0$ & $5 \cdot 8$ & ARIC, non-diabetic \\
\hline Mancini (1999)a & 10 & 131 & 0.13 & Caucasian & 50 & 7 & $27 \cdot 3$ & 3.5 & Italian, T2DM, men \\
\hline Mancini (1999)b & 10 & 312 & 0.18 & Caucasian & 45 & 6 & $25 \cdot 6$ & 3.3 & Italian, NGT, men \\
\hline Meirhaeghe (2000) & 45 & 1009 & 0.21 & Caucasian & 51 & 9 & $26 \cdot 6$ & 4.6 & WHO-MONICA + T2DM \\
\hline Memisoglu (2003) & 46 & 1158 & 0.23 & Caucasian & 54 & 7 & 28.9 & 5.9 & Women \\
\hline Nicklas (2001) & 47 & 70 & $0 \cdot 11$ & Caucasian & 60 & 7 & $32 \cdot 1$ & 4.6 & Healthy women, postmenopausal \\
\hline Niskanen (2003)a & 48 & 119 & 0.22 & Caucasian & 54 & 5 & $27 \cdot 1$ & $4 \cdot 3$ & NGT \\
\hline Niskanen (2003)b & 48 & 70 & 0.20 & Caucasian & 55 & 5 & 30.5 & $5 \cdot 2$ & T2DM \\
\hline Oh (2000) & 24 & 229 & 0.08 & Asian & 48 & 12 & $26 \cdot 0$ & 4.7 & Obese and non-obese \\
\hline Pisabarro (2004)a & 28 & 45 & 0.13 & Caucasian & 38 & 14 & $31 \cdot 7$ & $7 \cdot 1$ & NGT \\
\hline Pisabarro (2004)b & 28 & 11 & 0.55 & Caucasian & 52 & 9 & 39.4 & 7.5 & T2DM + IFG \\
\hline Radha (2006)a & 5 & 820 & 0.19 & Asian & 41 & 12 & 23.4 & 4.6 & South-Asians - Chennai (T2DM + NGT) \\
\hline Radha (2006)b & 5 & 156 & 0.23 & Asian & 33 & 11 & 23.9 & 3.6 & South-Asians - Dallas (T2DM + NGT) \\
\hline Radha (2006)c & 5 & 153 & 0.23 & Caucasian & 29 & 7 & $25 \cdot 0$ & 5.5 & Caucasians - Dallas (T2DM + NGT) \\
\hline Rhee (2006) & 25 & 253 & $0 \cdot 11$ & Korean & 51 & 6 & $24 \cdot 1$ & 2.9 & Women \\
\hline Ringel (1999) & 49 & 924 & 0.29 & Caucasian & - & & - & & Case-control (T2DM v. NGT) \\
\hline Rooij (2006) & 13 & 675 & 0.14 & Caucasian & 58 & 1 & $27 \cdot 9$ & $1 \cdot 2$ & Dutch, T2DM + IGT v. NGT \\
\hline
\end{tabular}




\begin{tabular}{|c|c|c|c|c|c|c|c|c|c|}
\hline \multirow[b]{2}{*}{ Study* } & \multirow[b]{2}{*}{ Reference } & \multirow[b]{2}{*}{ Subjects $(n)$} & \multirow{2}{*}{$\begin{array}{l}\text { Ala allele } \\
\text { frequency }\end{array}$} & \multirow[b]{2}{*}{ Study population } & \multicolumn{2}{|c|}{ Age (years) } & \multicolumn{2}{|c|}{$\mathrm{BMI}\left(\mathrm{kg} / \mathrm{m}^{2}\right)$} & \multirow[b]{2}{*}{ Observations } \\
\hline & & & & & Mean & SD & Mean & SD & \\
\hline Sánchez (2002)a & 50 & 210 & 0.17 & Caucasian & 48 & 8 & $27 \cdot 5$ & 3.8 & T2DM + IGT + NGT, obese and non-obese, men \\
\hline Sánchez (2002)b & 50 & 252 & 0.17 & Caucasian & 48 & 8 & 28.5 & 4.9 & T2DM + IGT + NGT, obese and non-obese, women \\
\hline Soriguer (2006) & 19 & 404 & 0.51 & Caucasian & 38 & 13 & & - & Obese and non-obese, Spanish \\
\hline Stefanski (2006) & 14 & 216 & 0.28 & Caucasian & 64 & 8 & $34 \cdot 2$ & 3.7 & T2DM, Poland \\
\hline Stumvoll (2001) & 51 & 68 & 0.25 & Caucasian & 29 & 7 & 23.7 & 3.6 & NGT \\
\hline Swarbrick (2001)a & 52 & 742 & 0.17 & Caucasian & 54 & 12 & 32.9 & $2 \cdot 6$ & CUDAS and Busselton, obese, T2DM + IGT + IFG + NGT \\
\hline Swarbrick (2001)b & 52 & 715 & 0.16 & Caucasian & 51 & 13 & $22 \cdot 0$ & 1.9 & CUDAS and Busselton, non-obese, T2DM + IGT + IFG + NGT \\
\hline Tai (2004)a & 26 & 3080 & 0.09 & Asian & 36 & 10 & 23.6 & $6 \cdot 7$ & NGT \\
\hline Tai (2004)b & 26 & 958 & 0.09 & Asian & 50 & 11 & $27 \cdot 0$ & 7.5 & T2DM \\
\hline Tavares (2005)a & 38 & 170 & 0.11 & Brazilian & 53 & 11 & $25 \cdot 9$ & 3.5 & NGT \\
\hline Tavares (2005)b & 38 & 207 & 0.17 & Brazilian & 54 & 13 & $30 \cdot 6$ & $7 \cdot 0$ & T2DM \\
\hline Temelkova (2004) & 32 & 622 & 0.28 & - & 56 & 7 & $27 \cdot 4$ & 4.9 & RIAD Study, non-diabetic \\
\hline Tschritter (2003)a & 21 & 406 & 0.23 & Caucasian & 34 & 18 & $25 \cdot 7$ & $5 \cdot 3$ & NGT, German \\
\hline Tschritter (2003)b & 21 & 54 & 0.24 & Caucasian & 42 & 11 & 28.5 & 7.9 & IGT, German \\
\hline Valve (1999) & 34 & 141 & 0.24 & Caucasian & 43 & 7 & 34.8 & 3.8 & Obese, non-diabetic, Finnish \\
\hline Vänttinen (2005)a & 53 & 72 & 0.29 & Caucasian & 29 & 8 & 23.0 & $2 \cdot 0$ & Non-obese, non-diabetic, Finnish \\
\hline Vänttinen (2005)b & 53 & 52 & 0.27 & Caucasian & 35 & 11 & $32 \cdot 3$ & 3.9 & Obese, non-diabetic, Finnish \\
\hline Yamamoto (2002) & 22 & 81 & 0.05 & Japanese & 43 & 7 & $24 \cdot 7$ & $2 \cdot 7$ & Men, hypertensive, non-diabetic \\
\hline Yamamoto (2002)a & 23 & 478 & 0.05 & Japanese & 48 & 9 & 23.2 & $2 \cdot 7$ & Men, non-diabetic \\
\hline Yamamoto (2002)b & 23 & 117 & 0.07 & Japanese & 46 & 8 & 20.7 & 2.9 & Women, non-diabetic \\
\hline
\end{tabular}

STOP-NIDDM, Study to Prevent Non Insulin Dependent Diabetes Mellitus; T2DM, type 2 diabetes mellitus; IGT, impaired glucose tolerance; NGT, normal glucose tolerance; JHU-WMC, Johns Hopkins University Weight Management Center; BLSA, Baltimore Longitudinal Study on Age; FUSION, Finland-United States Investigation of Non-Dependent Diabetes Mellitus Genetics Study; FCHL, Familial Combined Hyperlipidaemia; DESIR, Data from an Switzerland); ARIC, Atherosclerosis Risk in Communities; WHO-MONICA, Multinational MONltoring of trends and determinants of Cardiovascular diseases; IFG, impaired fasting glucose; CUDAS, Carotid Ultrasound Disease Assessment Study; Busselton, Busselton Population Health Survey; RIAD, Risk factors in Impaired glucose tolerance for Atherosclerosis and Diabetes.

* The same study with different populations is shown by $a, b, c$ or $d$. 


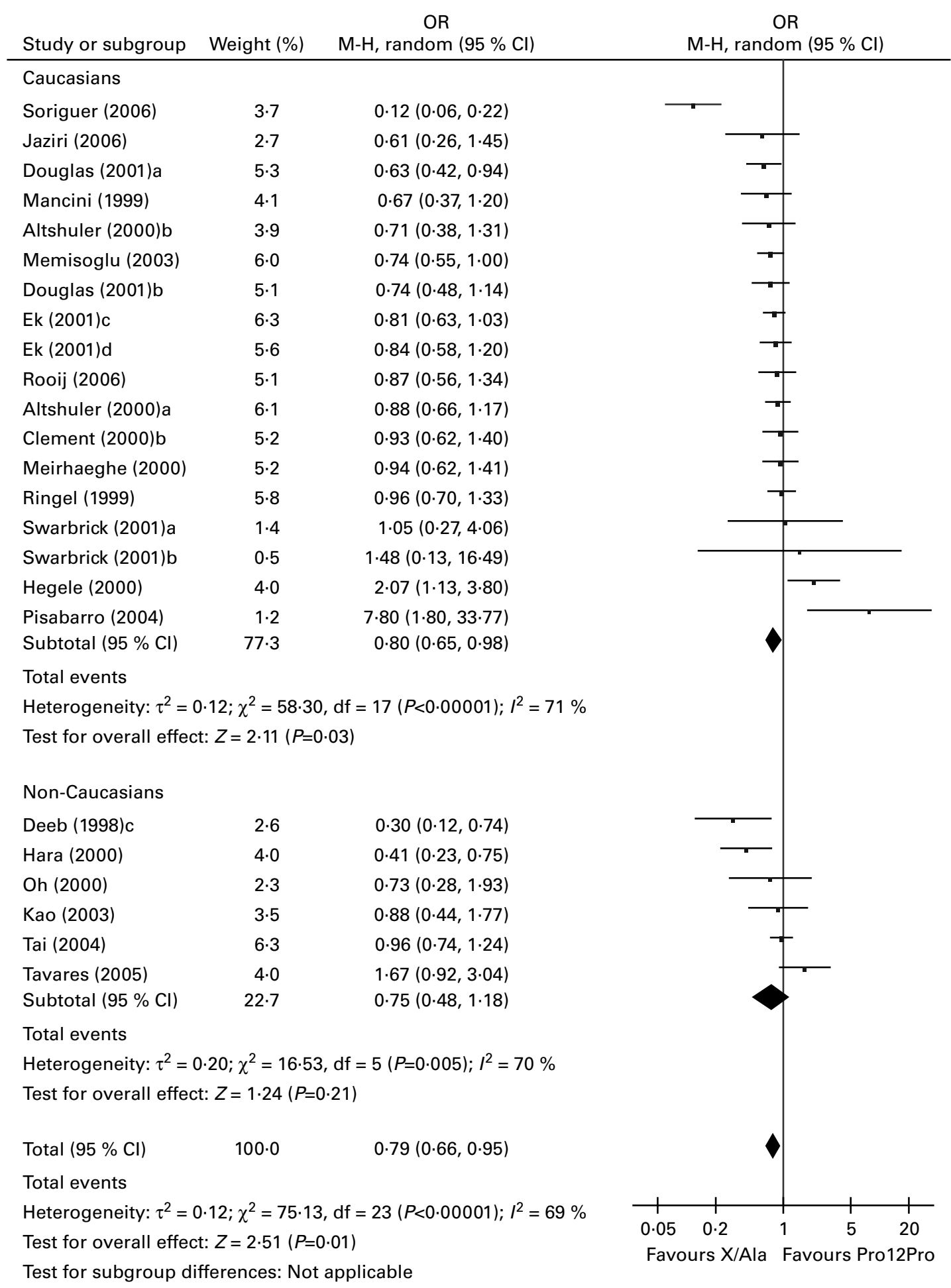

Fig. 1. Type 2 diabetes mellitus in eligible studies (sum of Pro12Ala and Ala12Ala (X/Ala) v. Pro12Pro). Estimated standardised effect sizes and Cl are given for the single studies and for global comparison. A negative standardised effect indicates that the corresponding frequency is smaller in X/Ala than in Pro12Pro. $\mathrm{M}-\mathrm{H}$, Mantel-Haenszel. The reference numbers for the studies can be found in Table 1. The same study with different populations is shown by a, b, $\mathrm{c}$ or $\mathrm{d}$.

this analysis was smaller ( $n$ 19) due to failure to provide the average BMI in some studies, so it was not possible to include these studies in one of the subgroups.

The association of serum insulin with the Ala allele showed that insulin concentration is lower in individuals of this allele compared with the wild genotype, but this relationship was not significant (OR $-0.04 ; 95 \% \mathrm{CI}-0.09$, $0.01 ; P=0.09)$; the sample proved to be heterogeneous $(P=0.02)$. The $I^{2}$ test was $30 \%$, indicating moderate inconsistency between studies. Grouping by ethnicity, Caucasians ( $n$ 36) and non-Caucasians ( $n$ 13), and excluding the multicentre Andrulionytè et $a l .^{(20)}$, produced the following results 


\begin{tabular}{|c|c|c|c|c|}
\hline \multirow{2}{*}{$\begin{array}{l}\text { Study or subgroup } \\
\text { Normal weight }\end{array}$} & \multirow[t]{2}{*}{ Weight (\%) } & \multirow[t]{2}{*}{$\begin{array}{l}\text { Standard mean difference } \\
\text { IV, fixed }(95 \% \mathrm{Cl})\end{array}$} & \multicolumn{2}{|c|}{$\begin{array}{l}\text { Standard mean differenc } \\
\text { IV, fixed }(95 \% \mathrm{Cl})\end{array}$} \\
\hline & & & & \\
\hline Hara (2000)b & 0.5 & $-0.50(-1.02,0.01)$ & & \\
\hline Vänttinen (2005)a & 0.5 & $-0.45(-0.96,0.06)$ & & \\
\hline Stumvoll (2001) & 0.5 & $-0.30(-0.85,0.25)$ & & - \\
\hline $\mathrm{Ek}(2001) \mathrm{b}$ & 2.5 & $-0.11(-0.34,0.13)$ & 一 & \\
\hline Hara (2000)a & 1.5 & $-0.04(-0.35,0.26)$ & $\bar{\tau}$ & - \\
\hline Tai (2004)a & $9 \cdot 2$ & $-0.04(-0.16,0.08)$ & & \\
\hline Radha (2006)a & 4.6 & $0.00(-0.17,0.17)$ & & - \\
\hline Yamamoto (2002)b & 0.3 & $0.00(-0.72,0.72)$ & & \\
\hline Radha (2006)b & $1 \cdot 0$ & $0.09(-0.28,0.46)$ & - & \\
\hline Yamamoto (2002) & 0.1 & $0.13(-0.87,1.14)$ & & \\
\hline Rhee (2006) & 0.9 & $0.16(-0.24,0.56)$ & - & \\
\hline Yamamoto (2002)a & 0.8 & $0.20(-0.21,0.61)$ & & \\
\hline Subtotal $(95 \% \mathrm{Cl})$ & $22 \cdot 4$ & $-0.04(-0.12,0.04)$ & & \\
\hline \multicolumn{5}{|c|}{$\begin{array}{l}\text { Heterogeneity: } \chi^{2}=9 \cdot 75, \mathrm{df}=11(P=0.55) ; l^{2}=0 \% \\
\text { Test for overall effect: } Z=1.06(P=0.29)\end{array}$} \\
\hline \multicolumn{5}{|l|}{ Overweight } \\
\hline Pisabarro (2004)b & 0.1 & $-0.51(-1.72,0.71)$ & & \\
\hline Vänttinen (2005)b & 0.5 & $-0.45(-0.96,0.06)$ & & \\
\hline Tavares (2005)b & $1 \cdot 1$ & $-0.39(-0.75,-0.03)$ & & \\
\hline Tavares (2005)a & 0.6 & $-0.34(-0.82,0.14)$ & & \\
\hline Niskaner (2003)b & 0.4 & $-0.33(-0.92,0.26)$ & & \\
\hline Sánchez (2002)b & $1 \cdot 2$ & $-0.33(-0.66,0.01)$ & & \\
\hline Pisabarro (2004)a & 0.2 & $-0.29(-1.15,0.57)$ & & \\
\hline Deeb (1998)a & 2.0 & $-0.27(-0.53,-0.01)$ & & \\
\hline Stefanski (2006) & 1.6 & $-0.21(-0.51,0.09)$ & & \\
\hline Mancini (1999)b & 1.7 & $-0.21(-0.49,0.08)$ & & \\
\hline Buzzetti (2004) & $6 \cdot 1$ & $-0.20(-0.35,-0.05)$ & -7 & \\
\hline Tschritter (2003)a & $2 \cdot 6$ & $-0.18(-0.41,0.06)$ & & \\
\hline Beamer (1998)d & $1 \cdot 1$ & $-0.16(-0.51,0.19)$ & & - \\
\hline Sánchez (2002)a & $1 \cdot 1$ & $-0.16(-0.52,0.20)$ & & - \\
\hline Eurlings (2003)a & 0.6 & $-0.14(-0.63,0.36)$ & & - \\
\hline Radha (2006)c & $1 \cdot 0$ & $-0.12(-0.50,0.26)$ & & - \\
\hline Baratta (2003) & $1 \cdot 3$ & $-0.09(-0.41,0.24)$ & & - \\
\hline Beamer (1998)b & 0.5 & $-0.08(-0.59,0.42)$ & & \\
\hline Tai (2004)b & 2.8 & $-0.07(-0.29,0.15)$ & - & - \\
\hline Lindi (2003)a & 1.0 & $-0.03(-0.41,0.34)$ & & - \\
\hline Frederiksen (2002) & $15 \cdot 3$ & $-0.02(-0.11,0.07)$ & & \\
\hline Lindi (2002) & 3.8 & $-0.01(-0.20,0.18)$ & & \\
\hline Ek (2001)a & 4.2 & $-0.01(-0.19,0.17)$ & & - \\
\hline Andrulionytè (2004) & 4.9 & $-0.01(-0.18,0.16)$ & & - \\
\hline Mancini (1999)a & 0.5 & $0.00(-0.51,0.51)$ & & \\
\hline Eurlings (2003)b & 0.8 & $0.00(-0.40,0.41)$ & & - \\
\hline Oh (2000) & 0.6 & $0.03(-0.45,0.51)$ & & \\
\hline Deeb (1998)b & $7 \cdot 1$ & $0.04(-0.10,0.18)$ & & - \\
\hline Temelkova (2004) & 4.5 & $0.05(-0.12,0.23)$ & & - \\
\hline Clement (2000)a & $2 \cdot 2$ & $0.08(-0.17,0.33)$ & & - \\
\hline Nicklas (2001) & 0.3 & $0.11(-0.59,0.81)$ & & \\
\hline Beamer (1998)c & $2 \cdot 0$ & $0.13(-0.14,0.39)$ & & - \\
\hline Valve (1999) & 0.9 & $0.22(-0.17,0.61)$ & & \\
\hline Lindi (2003)b & 0.5 & $0.26(-0.25,0.77)$ & & \\
\hline Niskaner (2003)a & 0.7 & $0.29(-0.14,0.73)$ & & \\
\hline Beamer (1998)a & 0.3 & $0.35(-0.33,1.04)$ & & \\
\hline Douglas (2001) & 1.5 & $0.45(0.15,0.75)$ & & - \\
\hline Tschritter (2003)b & 0.0 & $1.20(0.53,1.86)$ & & \\
\hline Subtotal (95\% Cl) & $77 \cdot 6$ & $-0.04(-0.09,-0.00)$ & & o \\
\hline \multicolumn{5}{|c|}{$\begin{array}{l}\text { Heterogeneity: } \chi^{2}=47.44, \mathrm{df}=36(P=0 \cdot 10) ; I^{2}=24 \% \\
\text { Test for overall effect: } Z=2.04(P=0.04)\end{array}$} \\
\hline Total $(95 \% \mathrm{Cl})$ & $100 \cdot 0$ & $-0.04(-0.08,-0.01)$ & 1 & a \\
\hline \multicolumn{3}{|c|}{$\begin{array}{l}\text { Heterogeneity: } \chi^{2}=57 \cdot 20, \mathrm{df}=48(P=0 \cdot 17) ; I^{2}=16 \% \\
\text { Test for overall effect: } Z=2 \cdot 30(P=0.02)\end{array}$} & $\begin{array}{ll}-1 & -0.5\end{array}$ & 0.5 \\
\hline
\end{tabular}

Test for subgroup differences: $\chi^{2}=0.00, \mathrm{df}=1(P=0.97), I^{2}=0 \% \quad$ Favours X/Ala Favours Pro12Pro

Fig. 2. Serum insulin in eligible studies (sum of Pro12Ala and Ala12Ala (X/Ala) $v$. Pro12Pro). Estimated standardised effect sizes and $\mathrm{Cl}$ are given for the single studies and for global comparison. A lower insulin concentration was significant for Ala allele carriers excluding Tschritter et al. ${ }^{(21 b)}(P=0.02)$. IV, insulin values. The reference numbers for the studies can be found in Table 1 . The same study with different populations is shown by a, b or $\mathrm{c}$. 


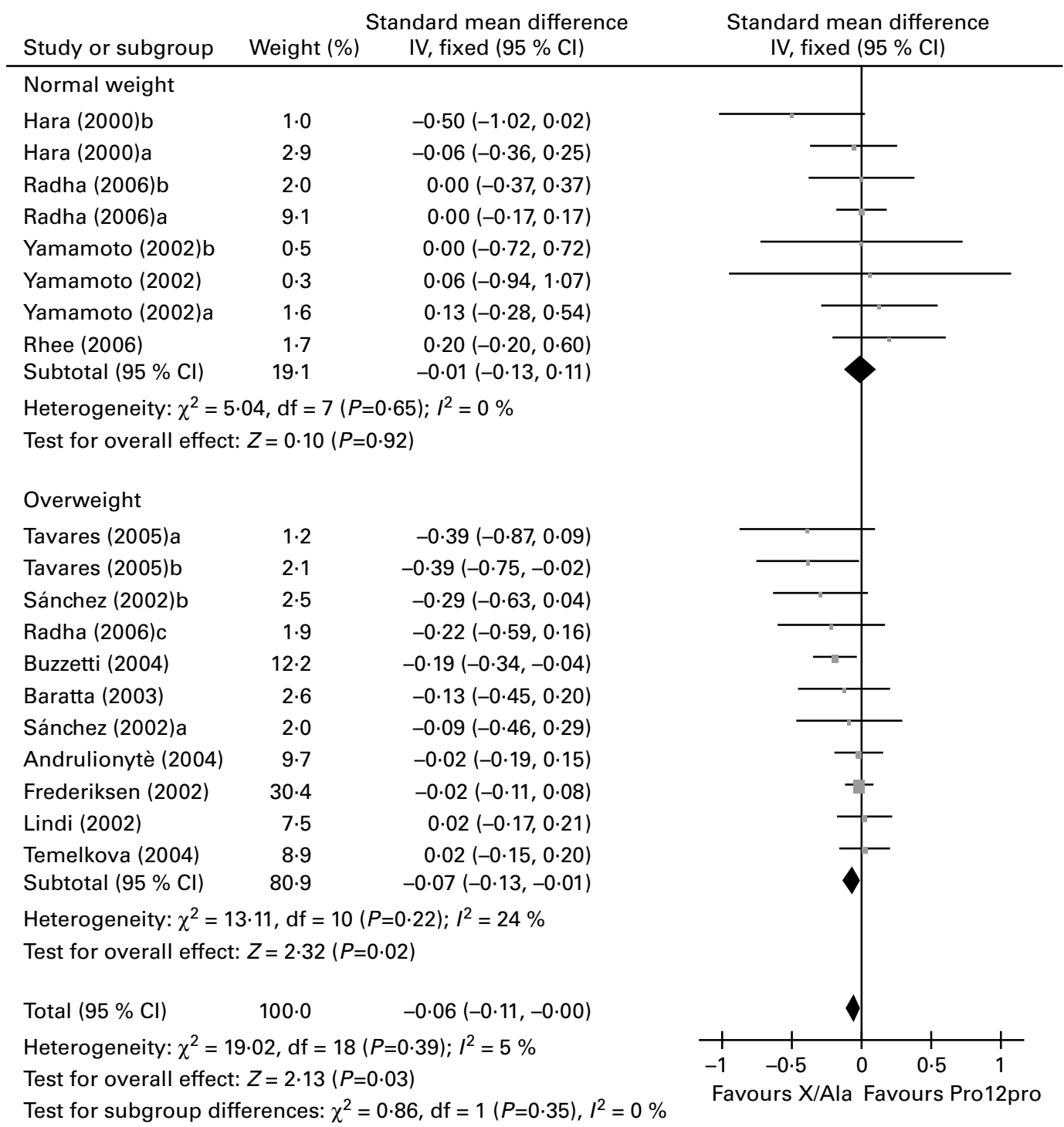

Fig. 3. Homeostasis model assessment for insulin resistance for eligible studies (sum of Pro12Ala and Ala12Ala (X/Ala) v. Pro12Pro). Estimated standardised effect sizes and $\mathrm{Cl}$ are given for the single studies and for global comparison. A negative standardised effect size indicates that the corresponding quantity is smaller in X/Ala than in Pro12Pro. IV, insulin values. The reference numbers for the studies can be found in Table 1 . The same study with different populations is shown by $a, b$ or $c$.

for Caucasians: OR - 0.04 (95\% CI $-0.11,0.02, P=0.22)$; and non-Caucasians: OR -0.05 (95\% CI $-0.12,0.03$, $P=0 \cdot 23)$. The subgroup of Caucasians showed heterogeneity $(P=0.01)$, with $39 \%$ of the studies contributing to this, according to results of $I^{2}$; however, the subgroup of nonCaucasians was homogeneous $(P=0 \cdot 49)$.

As seen in Fig. 2, the study that differed the most was Tschritter et al. ${ }^{(21 \mathrm{~b})}$, whose sample, after being excluded from the analysis, showed no global heterogeneity $(P=0.17)$; the meta-effect size calculation using a fixedeffects model proved to be significant (standardised mean difference: $-0.05 ; 95 \%$ CI $-0.09,-0.00 ; P=0.02)$. Thus, both subgroups, normal weight and overweight, presented themselves as homogeneous, with a negative association between the Ala allele and the concentration of insulin, although the effects were not significant $(P=0.029$ and $P=0 \cdot 07$, respectively).
When separating the diabetic ( $n$ 12) and glucose-tolerant ( $n$ 30) groups, if the study of Tschritter et al. ${ }^{(21 b)}$ study is removed, analysis of the Ala allele is associated with lower insulin concentrations for the diabetic group (standardised mean difference $-0 \cdot 13,95 \% \mathrm{CI}-0 \cdot 24,-0 \cdot 02, P=0.02$; heterogeneity $P=0.53$ ).

The same protective effect of the Ala allele is observed in the outcome of the association of HOMA-IR with polymorphism (Fig. 3), where the standardised effect size is significantly lower in the Ala allele carriers $(P=0.03)$ than in Pro12Pro genotype. The heterogeneity result in this analysis was not significant $(P=0 \cdot 39)$, and the inconsistency test showed very low inconsistency. According to the subdivisions shown in Fig. 3, the overweight subgroup showed the lowest HOMAIR values associated with the Ala allele $(P=0 \cdot 02)$. However, the test to evaluate the difference between the groups was not significant $(P=0 \cdot 35)$. 
In the analysis by ethnicity, both the Caucasian and non-Caucasian subgroups were homogeneous $(P=0.41$ and $P=0 \cdot 29$, respectively). Despite the association of each ethnic subgroup showing the same trend of the overall result (Caucasians' standardised mean difference -0.06, 95\% CI $-0 \cdot 11,0 \cdot 00, P=0.07$; non-Caucasians' standardised mean difference $-0.06,95 \%$ CI $-0.17,0.05, P=0.27)$, described previously, the associations were not significant.

\section{Discussion}

The studies presented in the present meta-analysis showed great variability in their frequency of polymorphism, ranging from 0.04 to 0.55 ; the samples with the lowest rates included non-Caucasian populations (African $^{(12)}$, Japanese $^{(7 \mathrm{c}, 8 \mathrm{a}, 8 \mathrm{~b}, 22,23 \mathrm{a}, 23 \mathrm{~b})}$, Korean ${ }^{(24,25)}$ and Asian descendants in general $\left.^{(26 a)}\right)$. The lower frequencies of polymorphism coincided with lower average BMI; however, in one population of Asians with a higher mean BMI, the frequency remained low ${ }^{(5 a)}$, similar to the results of previous studies (7c,8a,8b,12,22-26a).

Of the selected studies, twenty investigated Caucasian populations, and eleven European populations; only eight Asian populations, a North American and a South American population were included (Table 1). It should be noted that studies with European populations that did not clarify the ethnicity of the individuals included were then considered Caucasians, due to the low mixture of races of these populations. Interest in investigating the influence of the Pro12Ala polymorphism on the development of T2DM and insulin resistance appears to be higher in Caucasian populations, probably because of the greater frequency of this polymorphism among them.

In the present meta-analysis, twenty-four recent studies were included in the analysis of the association between the Ala allele and T2DM (Fig. 1), resulting in a protective effect of this allele to lower the risk of developing diabetes similar to Altshuler et al. ${ }^{(27)}$ ( $n$ 11; OR 0.79; $P=0.00007$ ) and Ek et al. ${ }^{(3)}$ ( $n$ 10; OR 0.81 ; $95 \%$ CI $0.72,0.91$; $P=0.00034)$. Furthermore, the risk of T2DM in Ala allele carriers could be shown to differ among ethnic groups, as the OR was lower in Caucasians and there was no significant risk in non-Caucasians (including Asians, African-Americans and South Americans). However, there was an increase in the overall $\mathrm{CI}$ and heterogeneity within Caucasian and non-Caucasian subgroups.

Regarding ethnicity, the meta-analysis performed by Ek et $a .^{(3)}$ showed that both Caucasians ( $n$ 7) and Asians ( $n$ 3) presented a significant negative association between the Ala allele and T2DM. However, there was a statistical difference between the OR of the two ethnic groups because the strength of association was lower for Asians than for Caucasians (Asian OR 0.42, 95\% CI 0.26, $0.67 v$. Caucasian OR 0.85, $95 \%$ CI $0.76,0.96 ; P=0.0033)$. Nevertheless, Radha et al. ${ }^{(5)}$ found in a study conducted with one Caucasian and two Asian populations that the Ala allele did not protect South Asian populations against T2DM, but did protect the Caucasians. This study found no significant difference between the polymorphism frequency in South Asian diabetics and non-diabetics (20 v. $23 \%$ in the Dallas cohort and 19 v. $19.3 \%$ in the Chennai cohort; $P>0.05$ ). Thus, both studies corroborate the present meta-analysis by suggesting that the Ala allele is a protective factor for T2DM in Caucasian populations.

Only four studies ${ }^{(7 \mathrm{c}, 9 \mathrm{a}, 8,19)}$ observed a significantly inverse association between the Ala allele and T2DM (i.e. found that the Ala allele is not associated with T2DM). Two of these analysed Nissei (second-generation Japanese) populations, one living in the Occident and another in Japan; the first $^{(7)}$ showed a strong association between the wild genotype (Pro12Pro) and T2DM (OR 4.35; $95 \%$ CI 1.24, 15.3; $P=0.028$ ). The other studies were carried out on Caucasians.

Pisabarro et al. $^{(28)}$ reported that Ala allele carriers developed T2DM at a younger age. Regarding sex, the Pro12Ala polymorphism was found to be strongly associated with T2DM in women but not in $\operatorname{men}^{(2)}$. The heterogeneity shown in Fig. 1 demonstrates that there is a high probability that the difference between OR is not due to chance (random error), but rather expresses different effects, probably influenced by age ${ }^{(28)}$, sex ${ }^{(2)}$ or even lipids in the diet ${ }^{(29)}$.

Those with the Ala allele had lower insulin concentrations in the global analysis, but this effect becomes significant when removing Tschritter et al. ${ }^{(21)}$, which used a sample of overweight subjects with impaired glucose tolerance. This result confirms the meta-analysis performed by Tönjes et $a l{ }^{(30)}$, who showed a standardised effect size of 0.168 $(P=0 \cdot 040)$ for Ala12Ala's association with lower insulin concentrations compared with the Pro12Pro genotype. However, they verified no significant serum insulin effect in association with the Ala allele. Their study assessed only non-diabetic samples $^{(30)}$ that still showed homogeneity $(P=0 \cdot 052)$.

Other studies found an association between the Ala allele and the lowest insulin concentration and increased sensitivity to insulin, regardless of $\operatorname{sex}^{(7)}, \mathrm{BMI}^{(27)}$, being non-diabetic ${ }^{(31)}$ and age ${ }^{(32)}$. Kao et al. $^{(12)}$ showed variations in BMI and fasting insulin depending on Pro12Ala genotype $(P=0.0027)$. Two other studies showed lower obesity levels associated with insulin genotype Pro12Pro ${ }^{(33,34)}$, but there was no apparent similarity between the studies that had shifted to the right on the graph of this analysis.

While the Ala allele is associated with a lower risk of developing diabetes, it is interesting to note that even under conditions of abnormal glucose tolerance, this polymorphism was associated with lower concentrations of insulin. This contributes to cardiovascular risk factors because hyperinsulinaemia is involved in several cardiovascular pathophysiological mechanisms ${ }^{(35-37)}$.

The beneficial effect of the Ala allele on sensitivity to insulin observed in the present study covered nineteen samples that analysed mean HOMA-IR, with one of the two samples composed of Brazilian diabetics being of significantly negative association $^{(38)}$. Using diabetic and non-diabetic samples in the same meta-analysis enriched the present study because it is assumed that despite the different values found for glucosetolerant individuals, the difference between the wild genotype and Ala allele averages would influence the final result.

The insulin resistance values were significantly lower in the group carrying the Ala allele (Fig. 3), as in Tönjes et al. ${ }^{(30)}$ in the obesity group, although a significant association in the overall HOMA-IR effect was present, highlighting the power of association in this study through homogeneity among the studies selected for this analysis. 
The present study has endeavoured to standardise the measures examined in order to minimise bias and heterogeneity between studies; stratification analysis was also performed to better characterise the subgroups.

\section{Final considerations}

These results suggest that the Ala allele is protective against T2DM development in Caucasians and not in some of the other populations. However, the mechanism has not been fully elucidated in the literature. It is important to emphasise that sensitivity to insulin is influenced by multiple factors; Pro12Ala polymorphism of the gene PPAR- $\gamma 2$ is one of them.

\section{Acknowledgements}

The authors thank Professor Paulo Borges of the Institute of Communication and Information Science and Technology in Health/FIOCRUZ for his assistance with statistical analysis and the Conselho Nacional de Pesquisa (CNPq) and Fundação Carlos Chagas Filho de Amparo à Pesquisa do Rio de Janeiro for funding.

The authors certify that they have contributed substantially to the conception and planning and interpretation of the data; we have contributed significantly to the preparation of the draft or to the critical revision of the content; and we participated in the approval of the final version of the manuscript.

We declare that there are no conflicts of interest.

\section{References}

1. Desvergne B \& Wahli W (1999) Peroxisome proliferatoractivated receptors: nuclear control of metabolism. Endocr Rev 20, 649-688.

2. Hegele RA, Cao H, Harris SB, et al. (2000) Peroxisome proliferator-activated receptor- $\gamma 2 \mathrm{P} 12 \mathrm{~A}$ and type 2 diabetes in Canadian Oji-Cree. J Clin Endocrinol Metab 85, 2014-2019.

3. Ek J, Andersen G, Urhammer SA, et al. (2001) Studies of the Pro12Ala polymorphism peroxisome proliferator-activated receptor- $\gamma 2(P P A R-\gamma 2)$ gene in relation to insulin sensitivity among glucose tolerant Caucasians. Diabetologia 44, 1170-1176.

4. Eurlings PMH, van der Kallen CJH, Vermeulen VMNJ, et al. (2003) Variants in the PPAR- $\gamma$ gene affect fat acid and glycerol metabolism in familial combined hyperlipidemia. Mol Genet Metab 80, 296-301.

5. Radha V, Vimaleswaram KS, Babu HNS, et al. (2006) Role of genetic polymorphism peroxisome proliferator-activated receptor- $\gamma 2$ Pro12Ala on ethnic susceptibility to diabetes in SouthAsian and Caucasian subjects. Diabetes Care 29, 1046-1051.

6. Groop L (2000) Genetics of the metabolic syndrome. Br J Nutr 83, Suppl. 1, S39-S48.

7. Deeb SS, Fajas L, Nemoto M, et al. (1998) A Pro12Ala substitution in PPAR 22 associated with decreased receptor activity, lower body mass index and improved insulin sensitivity. Nat Genet 20, 284-287.

8. Hara K, Okada T, Tobe K, et al. (2000) The Pro12Ala polymorphism in PPAR 2 may confer resistance to type 2-diabetes. Biochem Biophys Res Commun 271, 212-216.

9. Douglas JA, Erdos MR, Watanabe RM, et al. (2001) The peroxisome proliferator-activated receptor- $\gamma 2$ Pro12Ala variant association with type 2 diabetes and trait differences. Diabetes 50, $886-890$
10. Mancini FP, Vaccaro O, Sabatino L, et al. (1999) Pro12Ala substitution in the peroxisome proliferator-activated receptor$\gamma 2$ is not associated with type 2 diabetes. Diabetes 48 , $1466-1468$.

11. Matthews DR, Hosker JP, Rudenski AS, et al. (1985) Homeostasis model assessment: insulin resistance and $\beta$-cell function from fasting plasma glucose and insulin concentrations in man. Diabetologia 28, 412-419.

12. Kao WH, Coresh J, Shuldiner AR, et al. (2003) Pro12Ala of the peroxisome proliferator-activated receptor- $\gamma 2$ gene is associated with lower serum insulin levels in nonobese African Americans. Diabetes 52, 1568-1572.

13. Rooij SR, Painter RC, Philips DIW, et al. (2006) The effects of the Pro12Ala polymorphism of peroxisome proliferatoractivated receptor- $\gamma 2$ gene on glucose/insulin metabolism interact with pre-natal exposure to famine. Diabetes Care 29, $1052-1057$.

14. Stefanski A, Majkowska L, Ciechanowicz A, et al. (2006) Lack of association between the Pro12Ala polymorphism in PPAR 22 gene and the body weight changes, insulin resistance and chronic diabetic complications in obese patients with type 2 diabetes. Arch Med Res 37, 736-743.

15. Anonymous (2001) Système International (SI) Conversion Factors for Selected Laboratory Components. http://jama. ama-assn.org/content/vol295/issue1/images/data/103/DC6/JAMA_ auinst_si.dtl

16. The Nordic Cochrane Centre (2008) Review Manager (RevMan), computer program, version 5.0. Copenhagen: The Nordic Cochrane Centre, The Cochrane Collaboration.

17. Coutinho ESF (2002) Metanálise (Meta-analysis). In Epidemiologia (Epidemiology), 1st ed., pp. 447-455 [R Medronho, DM de Carvalho and KV Bloch, et al., editorss]. Rio de Janeiro: Editora Atheneu.

18. Higgins JP, Thompson SG, Deeks JJ, et al. (2003) Measuring inconsistency in meta-analyses. BMJ 327, 557-560.

19. Soriguer F, Morcillo S, Cardona F, et al. (2006) Pro12Ala polymorphism of the PPARG2 gene is associated with type 2 diabetes mellitus and peripheral insulin sensitivity in a population with a high intake of oleic acid. J Nutr 136, $2325-2330$

20. Andrulionytè L, Zacharova J, Chiasson JL, et al. (2004) Common polymorphisms of the PPAR 2 (Pro12Ala) and $P G C-1 \alpha$ (Gly482Ser) genes are associated with the conversion from impaired glucose tolerance to type 2 diabetes in the STOP-NIDDM trial. Diabetologia 47, 2176-2184.

21. Tschritter O, Fritche A, Stefan N, et al. (2003) Increased insulin clearance in peroxisome proliferator-activated receptor- $\gamma 2$ Pro12Ala. Metabolism 52, 778-783.

22. Yamamoto J, Kageyama S, Nemoto M, et al. (2002) PPAR 22 Pro12Ala polymorphism and insulin resistance in Japanese hypertensive patients. Hypertens Res 25, 25-29.

23. Yamamoto Y, Hirose H, Miyashita K, et al. (2002) PPAR 22 gene Pro12Ala polymorphism may influence serum level of an adipocyte-derived protein, adiponectin, in the Japanese population. Metabolism 51, 1407-1409.

24. Oh EY, Min KM, Chung JH, et al. (2000) Significance of Pro12Ala mutation in peroxisome proliferator-activated receptor- $\gamma 2$ in Korean diabetic and obese subjects. J Clin Endocrinol Metab 85, 1801-1804.

25. Rhee EJ, Oh KW, Lee WY, et al. (2006) Effects of two common polymorphisms of peroxisome proliferator-activated receptory gene on metabolic syndrome. Arch Med Res 37, $86-94$.

26. Tai ES, Corella D, Deurenberg-Yap M, et al. (2004) Differential effects of the C1431T and Pro12Ala PPAR $\gamma$ gene variants on plasma lipids and diabetes risk in an Asian population. $J$ Lipid Res 45, 674-685. 
27. Altshuler D, Hirshhorn JN, Klannemark M, et al. (2000) The common PPAR $\gamma$ Pro12Ala polymorphism is associated with decreased risk of type 2 diabetes. Nat Genet 26, 76-80.

28. Pisabarro RE, Sanguinetti C, Stoll M, et al. (2004) High incidence of type 2 diabetes in peroxisome proliferator-activated receptor $\gamma 2$ Pro12Ala carriers exposed to a high chronic intake of trans fatty acids and saturated fatty acids. Diabetes Care 27, 2251-2252.

29. Luan J, Browne PO, Harding AH, et al. (2001) Evidence for gene-nutrient interaction at the PPARg locus. Diabetes 50, 686-689.

30. Tönjes A, Scholz M, Loefler M, et al. (2006) Association of Pro12Ala polymorphism in peroxisome proliferator-activated receptor $\gamma$ with pre-diabetic phenotypes: meta-analysis of 57 studies on nondiabetic individuals. Diabetes Care 29, 2489-2497.

31. Buzzetti R, Petroni A, Ribaudo MC, et al. (2004) The common $P P A R-\gamma 2$ Pro12Ala variant is associated with greater insulin sensitivity. Eur J Hum Genet 12, 1050-1054.

32. Temelkova-Kurktschiev T, Hanefeld M, Chinetti G, et al. (2004) Ala12Ala genotype of the peroxisome proliferatoractivated receptor $\gamma 2$ protects against atherosclerosis. J Clin Endocrinol Metab 89, 4238-4242.

33. Clement K, Hercberg S, Passige B, et al. (2000) The Pro115Gln and Pro12Ala $\gamma$ gene mutations in obesity and type 2 diabetes. Int $J$ Obes 24, 391-393.

34. Valve R, Sivenius K, Miettinen R, et al. (1999) Two polymorphisms in the peroxisome proliferator-activated receptor- $\gamma$ gene are associated with severe overweight among obese women. J Clin Endocrinol Metab 84, 3708-3712.

35. Takahashi F, Hasebe N, Kawashima E, et al. (2006) Hyperinsulinemia is an independent predictor for complex atherosclerotic lesion of thoracic aorta in non-diabetic patients. Atherosclerosis 187, 336-342.

36. Glueck CJ, Lang JE, Tracy T, et al. (1999) Contribution of fasting hyperinsulinemia to prediction of atherosclerotic cardiovascular disease status in 293 hyperlipidemic patients. Metabolism 48, 1437-1444.

37. Adachi H, Jacobs DR, Hashimoto R, et al. (1998) Clustering of cardiovascular risk factors in hyperinsulinemia in Japanese without diabetes. Diabetes Res Clin Pract 40, 181-190.

38. Tavares V, Hirata RDC, Rodrigues AC, et al. (2005) Association between Pro12Ala polymorphism of the PPAR- $\gamma 2$ gene and the insulin sensitivity in Brazilian patients with type 2 diabetes mellitus. Diabetes Obes Metab 7, 605-611.

39. Baratta R, Di Paola R, Spampinato D, et al. (2003) Evidence for genetic epistasis in human insulin resistance: the combined effect of PC-1 (K121Q) and PPAR 2 (P12A) polymorphisms. J Mol Med 81, 718-723.

40. Beamer BA, Yen CJ, Andersen RE, et al. (1998) Association of the Pro12Ala variant in the peroxisome proliferator-activated receptor- $\gamma 2$ gene with obesity in two Caucasian populations. Diabetes 47, 1806-1808.

41. Frederiksen L, Brodbaek K, Fenger M, et al. (2002) Comment: studies of the Pro12Ala polymorphism of the PPAR- $\gamma 2$ gene in the Danish MONICA Cohort: homozygosity of the Ala allele confers a decreased risk of the insulin resistance syndrome. J Clin Endocrinol Metab 87, 3989-3992.

42. Jaziri R, Lobbens $\mathrm{S}$, Aubert $\mathrm{R}$, et al. (2006) The PPARG Pro12Ala polymorphism is associated with a decreased risk of developing hyperglycemia over 6 years and combines with effect of the APM1 G-11391A single nucleotide polymorphism: the Data from an Epidemiological Study on the Insulin Resistance Syndrome (DESIR) study. Diabetes 55, 1157-1162.

43. Lindi VI, Uusitupa MIJ, Lindström J, et al. (2002) Association of the Pro12Ala polymorphism in the PPAR- $\gamma 2$ gene with 3-year incidence of type 2-diabetes and body weight change in the Finnish Diabetes Prevention Study. Diabetes 51, $2581-2586$.

44. Lindi V, Schwab U, Louheranta A, et al. (2003) Impact of the Pro12Ala polymorphism of the PPAR- $\gamma 2$ gene on serum triacylglycerol response to $n-3$ fatty acid supplementation. Mol Genet Metab 79, 52-60.

45. Meirhaeghe A, Fajas L, Helbecque N, et al. (2000) Impact of the peroxisome proliferator-activated receptor $\gamma 2$ Pro12Ala polymorphism on adiposity, lipids and non-insulin-dependent diabetes mellitus. Int J Obes 24, 195-199.

46. Memisoglu A, Hu FB, Hankinson SE, et al. (2003) Prospective study of the association between the proline to alanine codon 12 polymorphism in the PPAR $\gamma$ gene and type 2 diabetes. Diabetes Care 26, 2915-2917.

47. Nicklas BJ, van Rossum EFC, Berman DM, et al. (2001) Genetic variation in the peroxisome proliferator-activated receptor- $\gamma 2$ gene (Pro12Ala) affects metabolic responses to weight loss and subsequent weight regain. Diabetes 50, 2172-2176.

48. Niskanen L, Lindi V, Erkkilä A, et al. (2003) Association of the PRO12ALA polymorphism of the PPAR- $\gamma 2$ gene with oxidized low-density lipoprotein and cardiolipin autoantibodies in nondiabetic and type 2 diabetic subjects. Metabolism 52, 213-217.

49. Ringel J, Engeli S, Distler A, et al. (1999) Pro12Ala missense mutation of the peroxisome proliferator-activated receptor $\gamma$ and diabetes mellitus. Biochem Biophys Res Commun 254, 450-453.

50. González Sánchez JL, Serrano Ríos M, Fernández Perez C, et al. (2002) Effect of the Pro12Ala polymorphism of the peroxisome proliferator-activated receptor $\gamma-2$ gene on adiposity, insulin sensitivity and lipid profile in the Spanish population. Eur J Endocrinol 147, 495-501.

51. Stumvoll M, Wahl HG, Löblein K, et al. (2001) Pro12Ala polymorphism in the peroxisome proliferator-activated receptor- $\gamma 2$ gene is associated with increased antilipolytic insulin sensitivity. Diabetes 50, 876-881.

52. Swarbrick MM, Chapman CML, McQuillan B, et al. (2001) A Pro12Ala polymorphism in the human peroxisome proliferator-activated receptor- $\gamma 2$ is associated with combined hyperlipidaemia in obesity. Eur J Endocrinol 144, 277-282.

53. Vänttinen M, Nuutila $\mathrm{P}$, Pihlajamäki J, et al. (2005) The effect of the Ala12 allele of the peroxisome proliferator-activated receptor- $\gamma 2$ gene on skeletal muscle glucose uptake depends on obesity: a positron emission tomography study. J Clin Endocrinol Metab 90, 4249-4254. 